\title{
Rhizosphere pH and phosphorus forms in an Oxisol cultivated with soybean, brachiaria grass, millet and sorghum
}

\author{
Evandro Luiz Schoninger ${ }^{\star}{ }^{\star}$, Luciano Colpo Gatiboni, Paulo Roberto Ernani
}

UDESC/CAV - Depto. de Agronomia, Av. Luiz de Camões, 2090, Conta Dinheiro - 88520-000 - Lages, SC - Brasil.

*Corresponding author <schoningere@cena.usp.br>

Edited by: Eros Artur Bohac Francisco / Luís Reynaldo Ferracciú Alleoni
Received April 28, 2011

Accepted January 10, 2012

\begin{abstract}
Plants have shown different responses to fertilization with rock phosphate, including responses through alteration of the attributes of rhizospheric soil. The objective of this study was to evaluate soil pH alterations and alterations in the contents of forms of phosphorus in the rhizosphere of soil fertilized with rock phosphate as a result of cultivation of species of plants. An experiment was developed under greenhouse conditions to evaluate alterations in the $\mathrm{pH}$ and in the forms of phosphorus in the rhizosphere of an Oxisol fertilized with rock phosphate and cultivated with four species. Treatments consisted of the cultivation of four species of soybean - Glycine max (L.) Merrill, brachiaria grass - Brachiaria brizantha Hochst Stapf, millet - Pennisetum glaucum (L.) R. Brown, and sorghum - Sorghum bicolor (L.) Moench grown in PVC columns filled with soil and divided with a nylon screen ( $25 \mu \mathrm{m}$ mesh) to impede root growth in part of the column. After 45 days of cultivation, the soil was divided into the layers of $0-1,1-2,2-3,3-4,4-5,5-7,7-9$, and 9-14 $\mathrm{mm}$ from the rhizoplane and air dried to determine $\mathrm{pH}$ and $\mathrm{P}$ contents through Hedley fractionation. In the 1-2 and 2-3 mm layers, soybean cultivation caused an increase in $\mathrm{pH}$ when compared to the control treatment (without plants). In the other layers, there were no alterations in $\mathrm{pH}$ due to cultivation of plants. The cultivation of millet, brachiaria grass, and sorghum reduced the inorganic $\mathrm{P}$ content in the most labile forms only in the 0-1 mm layer from the rhizoplane.

Keywords: Brazilian savanna soils, phosphorus fractionation, cover plants, rock phosphate, rhizospheric soil
\end{abstract}

\section{Introduction}

Phosphorus (P) deficiency has been one of the greatest limitations to increase productivity of crops in tropical regions, with food production being highly dependent on the use of phosphate fertilizers, especially from soluble sources. These sources provide good $\mathrm{P}$ availability soon after their application (Prochnow et al., 2004); however, they are costly and present a low residual effect due to significant adsorption of the $\mathrm{P}$ derived from fertilizers on soil colloids.

Seeking to reduce crop production costs, an increase in the use of less soluble $\mathrm{P}$ sources, such as rock phosphates (RP), has been observed. Such phosphates require low $\mathrm{pH}$ values and $\mathrm{P}$ and $\mathrm{Ca}$ soil sinks to favor their dissolution and $\mathrm{P}$ availability (Robinson and Syers, 1990; Sanyal and Datta, 1991). Nevertheless, the soil characteristics that favor RP dissolution may be limiting factors for plant development and, for this reason, many studies have been made on the micro region of the soil that may present characteristics desirable for RP dissolution due to plant development - the rhizosphere (Hinsinger and Gilkes, 1995; Pearse et al., 2007; Perez et al., 2007; Ramirez et al., 2001; Zoysa et al., 1997, 1998). The alterations caused in the rhizospheric soil attributes vary according to the cultivated plant species (Bertrand et al., 1999; Hinsinger and Gilkes, 1996, 1997; Morel and Hinsiger, 1999; Pearse et al., 2006, 2007). Thus, the

\$Present address: USP/CENA - Lab. de Isótopos Estáveis, Av. Centenário, 303 -13400-970 - Piracicaba, SP - Brasil. identification of species more capable of accessing less available forms of $\mathrm{P}$ and later introduction of them in a crop rotation system may benefit the plants that are more sensitive to $\mathrm{P}$ deficiency through decomposition of plant residues, thus making available the $\mathrm{P}$ present in their tissues (Sousa et al., 2004).

In the central region of Brazil, brachiaria grass (Brachiaria brizantha Hochst Stapf), sorghum (Sorghum bicolor (L.) Moench), and millet (Pennisetum glaucum (L.) R. Brown) have presented a good potential as cover plants during the period between harvests of soybean (Glycine max (L.) Merrill). Nevertheless, the potential of these plants in utilizing mechanisms for increasing $\mathrm{P}$ uptake at the time of use of rock phosphates has not yet been tested. The objective of this study was to evaluate alterations in the $\mathrm{pH}$ and in the contents of different forms of phosphate in the rhizosphere of a soil fertilized with rock phosphate as a result of the cultivation of soybeans, brachiaria grass, millet and sorghum.

\section{Materials and Methods}

The experiment was carried out from January to March 2010 in Lages, state of Santa Catarina, Brazil. Soil samples collected from the $0-20 \mathrm{~cm}$ layer of a clayey Typic Haplustox (Soil Survey Staff, 2010) were used. The soil was managed as pasture with Brachiaria brizantha in Matupá, state of Mato Grosso, Brazil (10¹0'18" S; $\left.54^{\circ} 51^{\prime} 33^{\prime \prime} \mathrm{W}\right)$. Samples were air dried and passed through a sieve of $2 \mathrm{~mm}$ mesh, and its analyses presented the following characteristics: $\mathrm{pH}$ in $0.01 \mathrm{~mol} \mathrm{~L}^{-1} \mathrm{CaCl}_{2}$ : 4.9; $\mathrm{P}$ 
(resin): $0.8 \mathrm{mg} \mathrm{dm}^{-3} ; \mathrm{K}: 1.4 \mathrm{mmol} \mathrm{dm}^{-3} ; \mathrm{Ca}: 7.0 \mathrm{mmol}_{\mathrm{c}}$ $\mathrm{dm}^{-3} ; \mathrm{Mg}: 4.2 \mathrm{mmol}_{\mathrm{c}} \mathrm{dm}^{-3} ; \mathrm{Al}: 4.2 \mathrm{mmol}_{\mathrm{c}} \mathrm{dm}^{-3} ; \mathrm{H}+\mathrm{Al}$ : $54.8 \mathrm{mmol}_{\mathrm{c}} \mathrm{dm}^{-3}$; organic matter: $30 \mathrm{~g} \mathrm{dm}^{-3} ; \mathrm{CEC}_{(\mathrm{pH} 7.0)}$ : $67.4 \mathrm{mmol}_{\mathrm{c}} \mathrm{dm}^{-3}$; base saturation: $19 \%$; sand: $296 \mathrm{~g} \mathrm{~kg}^{-1}$; silt: $165 \mathrm{~g} \mathrm{~kg}^{-1}$; clay: $538 \mathrm{~g} \mathrm{~kg}^{-1}$.

For the purpose of raising the base saturation of the soil to $50 \%$, as recommended by Sousa and Lobato (2004), application and incorporation of dolomitic lime (filler) at a rate equivalent to $2.4 \mathrm{t} \mathrm{ha}^{-1}$ was performed. Afterwards, the soil was incubated for 20 days with water content close to field capacity, seeking to provide reaction of the lime particles with the soil. Then, the equivalent of $140 \mathrm{~kg} \mathrm{ha}^{-1}$ of $\mathrm{P}_{2} \mathrm{O}_{5}\left(14 \mathrm{mg}\right.$ of $\mathrm{P}_{2} \mathrm{O}_{5}$ per pot) and $100 \mathrm{~kg} \mathrm{ha}^{-1}$ of $\mathrm{K}_{2} \mathrm{O}$ (10 mg of $\mathrm{K}_{2} \mathrm{O}$ per pot) were added to the soil in the forms of Arad rock phosphate and potassium chloride respectively.

The experiment was carried out in a greenhouse based on the methodologies described by Chen et al. (2002), Kuchenbuch and Jungk (1982) and Zoysa et al. (1997). For this purpose, PVC cylinders of $5 \mathrm{~cm}$ diameter and $10 \mathrm{~cm}$ height were used, which were composed of an upper column of $5 \mathrm{~cm}$ height, an intermediate column of $2 \mathrm{~cm}$ height and a lower column of $3 \mathrm{~cm}$ height. The base of the upper column received a nylon screen with a 25 $\mu \mathrm{m}$ mesh (to impede root growth to the lower columns) and, at the base of the lower column, a nylon screen of $50 \mu \mathrm{m}$ mesh was fastened for water entry. These columns were filled with soil until reaching a density of $1.0 \mathrm{~g} \mathrm{~cm}^{-3}$, and then arranged on $12 \mathrm{dm}^{-3}$ pots filled with sand. Due to the contact between the PVC cylinders and the sand, soil moisture was maintained through capillary rise, since the pots with sand were connected to a water container maintaining the water level in the pots constant $15 \mathrm{~cm}$ below the PVC columns), providing a water potential of $-1.5 \mathrm{kPa}$ at the base of the soil columns (Figure 1).

A randomized block design was used with four replicates, the blocks representing the sand pots. Each experimental unit consisted of three PVC columns to

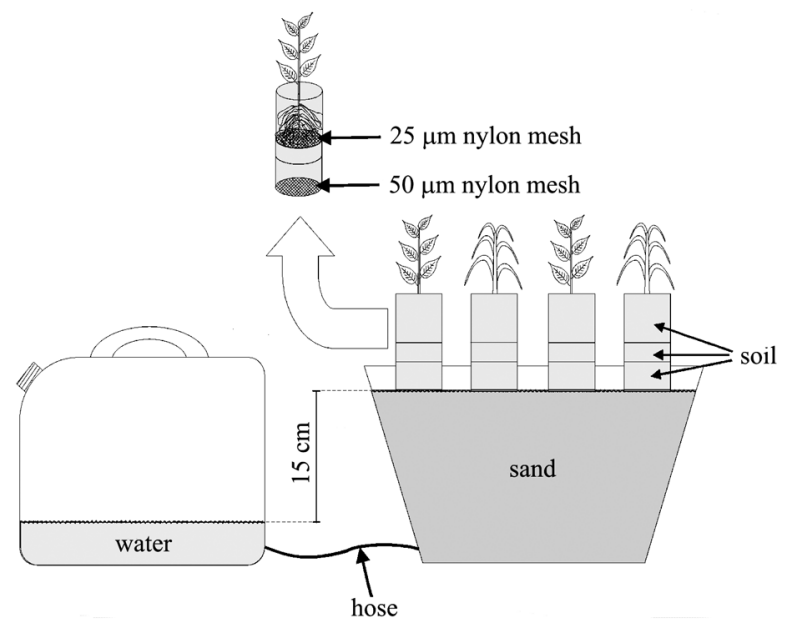

Figure 1 - Schematic representation of the system for maintenance of moisture and constitution of PVC columns with nylon mesh to prevent root growth. obtain the quantity of soil required for the soil chemical analyses, totaling 15 PVC columns per block. Treatments consisted of the cultivation of soybeans - Glycine $\max$ (L.) Merrill, brachiaria grass - Brachiaria brizantha Hochst Stapf, millet - Pennisetum glaucum (L.) R. Brown, and sorghum - Sorghum bicolor (L.) Moench, plus a control (absence of plants).

The $\mathrm{P}$ content in the seeds of each species was performed drying three seed samples in a laboratory oven at $65^{\circ} \mathrm{C}$, followed by grinding and sulfuric acid addition as described by Tedesco et al. (1995), followed by P concentration determination in the extract through the colorimetric method proposed by Murphy and Riley (1962).

Two viable seeds of each species were planted per pot. The seeds were pre-germinated in sheets of moistened paper, and only seeds that presented root emergence were selected. On the day of planting, the experimental units received the application of $25 \mathrm{mg} \mathrm{kg}^{-1}$ of $\mathrm{N}$ in the form of urea, in solution (except for the soybeans), and in the pots where the soybeans were planted, application of liquid inoculant (Bradyrhizobium japonicum) was made at the dose corresponding to $200 \mathrm{~mL} \mathrm{ha}^{-1}$. Five days after planting, thinning of the plants was performed, leaving only one plant per pot. At 14 and 28 days after planting, application of $25 \mathrm{mg} \mathrm{kg}^{-1}$ of $\mathrm{N}$ was made in the pots (except for the soybeans) as a solution, using urea.

Forty five days after planting, plants were cut at soil surface. Then roots from each upper pot were separated from the soil and the separation of the PVC columns was also performed. The soil contained in the intermediate column, whose upper part was in contact with the mesh that impeded root growth, was divided into the following layers: $0-1,1-2,2-3,3-4,4-5,5-7,7-9$, and $9-14 \mathrm{~mm}$. For this purpose, the intermediate column containing moist soil was fastened in a metallic cylinder with the aid of a bracket. At the base of the column (side opposite to that which was in contact with the nylon mesh) a plastic disk with a diameter identical to the internal diameter of the column was added, with this disk coupled to a threaded metallic rod with markings at each millimeter for measurement of the soil layers to be collected with the aid of a metallic blade. The soil samples were air dried for later determination of $\mathrm{pH}$ in $0.01 \mathrm{~mol} \mathrm{~L}^{-1} \mathrm{CaCl}_{2}$ as described by Tedesco et al. (1995), and the main forms of soil phosphorus following the methodology proposed by Hedley et al. (1982), namely: $\mathrm{P}$ extractible by ion exchange resin $\left(\mathrm{P}_{\text {resin }}\right)$; inorganic $\mathrm{P}$ extractible with $0.5 \mathrm{~mol} \mathrm{~L} \mathrm{~L}^{-1}$ sodium bicarbonate $\left(\mathrm{Pi}_{\text {bic }}\right)$; organic $\mathrm{P}$ extractible with $0.5 \mathrm{~mol} \mathrm{~L}^{-1}$ sodium bicarbonate $\left(\mathrm{Po}_{\text {bic }}\right)$; inorganic $\mathrm{P}$ extractible with $0.1 \mathrm{~mol} \mathrm{~L}^{-1} \mathrm{NaOH}$ after sonication $\left(\mathrm{Pi}_{\text {hid }}\right)$; organic $\mathrm{P}$ extractible with $0.1 \mathrm{~mol}$ $\mathrm{L}^{-1} \mathrm{NaOH}$ after sonication $\left(\mathrm{Po}_{\text {hid }}\right)$; inorganic $\mathrm{P}$ extractible with $0.5 \mathrm{~mol} \mathrm{~L}^{-1} \mathrm{HCl}\left(\mathrm{P}_{\mathrm{HCl}}\right)$, and $\mathrm{P}$ extractible after soil digestion with $\mathrm{H}_{2} \mathrm{SO}_{4}+\mathrm{H}_{2} \mathrm{O}_{2}\left(\mathrm{P}_{\text {residual }}\right)$. The determination of the $\mathrm{P}$ concentration in the extracts was performed by colorimetry (Murphy and Riley, 1962).

After harvest plants were dried in a laboratory oven at $65{ }^{\circ} \mathrm{C}$ until constant weight and were then 
weighed for determination of dry matter of the above ground part and roots. Evaluation of the P content in the plant tissues was performed through the sulfuric acid method described by Tedesco et al. (1995). Determination of $\mathrm{P}$ in the extracts of plant tissues was performed using the colorimetric method proposed by Murphy and Riley (1962). Based on the quantity of $\mathrm{P}$ in the seeds and in the plant tissue, the percentage of $\mathrm{P}$ accumulated in the tissue derived from the seed (PPS) was calculated for each species as follows: PPS $(\%)=(\mathrm{P}$ quantity in a seed $)$ / (P quantity in the plant tissue $) \times 100$.

The data were submitted to analysis of variance $(p \leq 0.05)$. Comparison of the means by the Tukey test $(p \leq 0.05)$ was carried out. For the soil data in which there was effect of the treatments, indicated by the F test, the means of each species were compared with the mean of the control by the Dunnett test; the results of phosphorus contents in the soil and $\mathrm{pH}$ values were presented based on the difference $(\Delta)$ between the means of each species and the control, calculated as: $\Delta=$ mean of the species - mean of the control.

\section{Results and Discussion}

Soybean cultivation provided greater $\mathrm{pH}$ values in relation to the control $(\Delta \mathrm{pH})$ only in the 1-2 and 2-3 $\mathrm{mm}$ layers (Figure 2A). The other species did not differ from the control in relation to $\mathrm{pH}$. The differences between the $\mathrm{pH}$ values in the 1-2 and 2-3 mm layer were not correlated to plant species because the $\mathrm{pH}$ variation with soybean cultivation did not occur in the layer in which greater influence of the roots $(0-1 \mathrm{~mm})$ would be expected. Nevertheless, one of the possible causes for this $\mathrm{pH}$ variation may have been the lack of application of nitrogen fertilizer in the pots cultivated with soybean cultivation and the use of urea as a source of $\mathrm{N}$ in the pots with cultivation of gramineous plants and without plant cultivation (control). Although urea hydrolysis provides soil $\mathrm{pH}$ elevation due to transformation of the $\mathrm{R}$ $\mathrm{NH}_{2}$ in $\mathrm{NH}_{4}^{+}$(consumption of an $\mathrm{H}^{+}$ion), generally the final balance of urea application is acidification because, under normal conditions, most of the soil $\mathrm{NH}_{4}^{+}$is oxi- dized to $\mathrm{NO}_{3}^{-}$(release of two $\mathrm{H}^{+}$ions), leading to a final balance of release of one $\mathrm{H}^{+}$ion in the soil for each $\mathrm{N}$ atom added by the urea fertilizer (Ernani, 2008). In this sense, as the soybeans have probably not altered the soil $\mathrm{pH}$, the difference observed between the soybeans and the control in the 1-2 and 2-3 mm layers was due to the reduction of $\mathrm{pH}$ in the control treatment as a response to urea application to the soil. In spite of having observed soil $\mathrm{pH}$ alteration with the application of $\mathrm{N}$, this variation did not pass 0.2 units (Figure 2A), not being very expressive when compared to the variations found in the field (two to three units).

Soybeans most accumulated $\mathrm{P}$ in tissue (above ground part and roots), while brachiaria grass and sorghum accumulated the least quantities, and the millet did not differ from the other species (Table 1). Soybean was the sole crop in which PPS reached a value greater than $100 \%$. Thus, we can infer that the main source of $\mathrm{P}$ for this crop during the period of the experiment was the seed itself and not the soil.

Sorghum was the only species that reduced the $\mathrm{P}_{\text {resin }}$ content, however, only in the layer nearest to the roots (Figure 2B), since in the other layers there was no effect from the cultivation of the species. There was a reduction of the $\mathrm{Pi}_{\text {bic }}$ content with the cultivation of brachiaria grass, millet and sorghum only in the layer nearest to the roots. With soybean cultivation, no difference

Table 1 - Phosphorus accumulated in plant tissue (PAT), one hundred seed weight (W100), phosphorus content in seeds (PCS), amount of phosphorus per seed (APS) and percentage of phosphorus accumulated in the tissue derived from the seed (PPS).

\begin{tabular}{lccccr}
\hline Plant & PAT & W100 & PCS & APS & PPS \\
\hline \multirow{3}{*}{ Brachiaria grass } & mg per pot & g & $\mathrm{g} \mathrm{kg}^{-1}$ & mg per seed & $\%$ \\
Millet & $0.214 \mathrm{~b}$ & 0.66 & 3.5 & 0.023 & 11 \\
Soybean & $0.287 \mathrm{ab}$ & 0.57 & 3.7 & 0.021 & 7 \\
Sorghum & $0.442 \mathrm{a}$ & 10.82 & 4.3 & 0.465 & 105 \\
\hline F value & $0.146 \mathrm{~b}$ & 2.48 & 2.6 & 0.064 & 44 \\
\hline CV (\%) & $7.0^{* *}$ & - & - & - & - \\
\hline
\end{tabular}

Means followed by the same letters in the columns did not differ (Tukey test, $p$ $\leq 0.05) .{ }^{* *}=p \leq 0.01$. CV $=$ coefficient of variation.
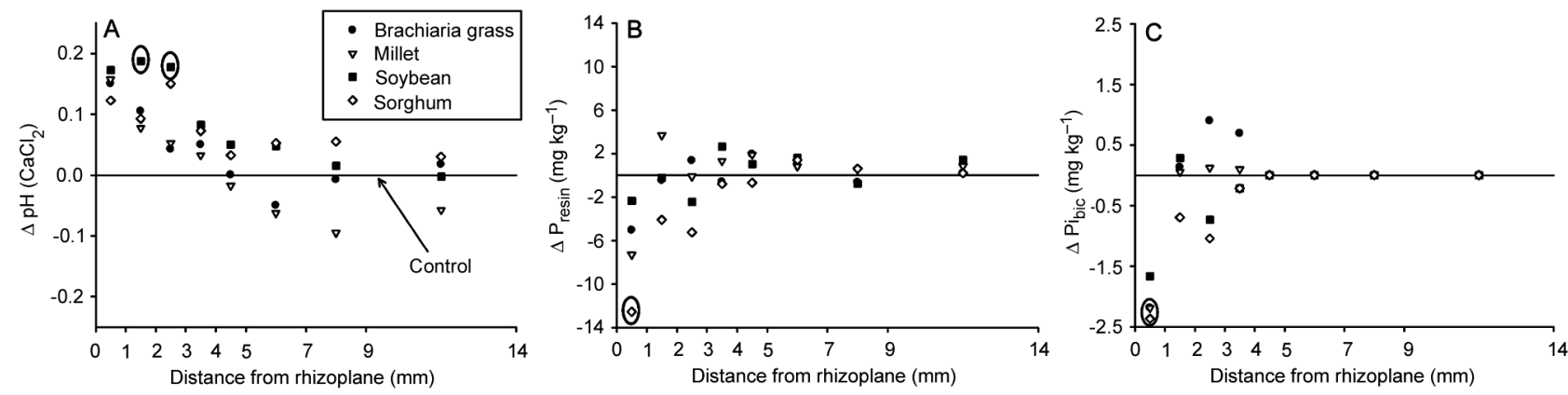

Figure $2-\mathrm{pH}(\mathrm{A}), \mathrm{P}_{\text {resin }}(\mathrm{B})$ and $\mathrm{Pi}_{\text {bic }}(\mathrm{C})$ differences between each treatment and control $(\Delta)$ in layers of soil from rhizoplane caused by the cultivation of different plants. In each layer, circular symbol indicates difference between treatment and control by Dunnett test $(p \leq 0.05)$. 
was observed in the content of this form of $\mathrm{P}$ in any of the layers (Figure 2C), probably because of the great quantity of $\mathrm{P}$ in the soybean seed (Table 1). Assuming that $\mathrm{P}_{\text {resin }}$ and the $\mathrm{Pi}_{\text {bic }}$ are $\mathrm{P}$ available forms to the plants (Beck and Sanches, 1994; Gatiboni et al., 2007; Guo and Yost, 1998; Hedley et al., 1982; Henriquez and Killorn, 2005; Sharpley and Smith, 1985; Stewart and Tiessen, 1987; Tiessen et al., 1984), we can observe that there was depletion of $\mathrm{P}$ with the cultivation of plants, shown by the reduction in the contents of these forms in the layer nearest to the roots. Nevertheless, the reduction of $\mathrm{Pi}_{\text {bic }}$ in all the treatments with gramineous plants and of $\mathrm{P}_{\text {resin }}$ only with the cultivation of sorghum does not necessarily indicate a preferential uptake of this form by specific species, but rather that there is an interconnection between the compartments of the $\mathrm{P}$ fractions in the soil, as already reported by Gatiboni et al. (2007). In this way, with the uptake of the $\mathrm{P}_{\text {resin }}$ by the plants, it is probable that this $\mathrm{P}$ form has been made up by other forms like $\mathrm{Pi}_{\text {bic }}$ thus explaining its reduction with the cultivation of brachiaria grass and millet.

Only the gramineous plants led to a depletion of $\mathrm{P}$ in the layer nearest to the roots, showing their greater uptake capacity of this nutrient during the period in which the experiment was carried out. As previously mentioned, the main source of $\mathrm{P}$ for the soybeans during the evaluated period must have been the seed itself, thus reflecting low need of uptake of this nutrient and absence of $\mathrm{P}$ depletion of the soil. This positive relationship between the quantity of $\mathrm{P}$ in the seed and the dry matter production of the plants has already been reported for soybeans (Trigo et al., 1997), wheat (Zhu and Smith, 2001), clover (Thomson and Bolger, 1993), oats (Zhang et al., 1990) and rice (Ros et al., 1997), confirming the hypothesis that during the beginning of their development, certain species of plants may survive only with the P derived from the seed (Grant et al., 2001).

Although the $\mathrm{Po}_{\text {bic }}$ is also considered a labile form of P (Beck and Sanches, 1994; Gatiboni et al., 2007; Guo and Yost, 1998; Hedley et al., 1982; Henriquez and Killorn, 2005; Sharpley and Smith, 1985; Stewart and Tiessen, 1987; Tiessen et al., 1984), the influence of the cultivation of plants on this variable has not been observed (Figure 3A). The $\mathrm{Po}_{\text {bic }}$ is a form of $\mathrm{P}$ associated with the microbial biomass of the soil (Chen et al., 2002; Helal and Sauerbeck, 1984) and its depletion occurs mainly when the contents of $\mathrm{P}_{\text {resin }}$ and $\mathrm{Pi}_{\text {bic }}$ are not sufficient to supply the demand of the plants. Therefore, as the availability of inorganic $\mathrm{P}$ in the layers nearest to the roots was not limiting and the organic carbon derived from the roots stimulates microbial growth and activity in the rhizosphere (Martin, 1983; Toal et al., 2000), not only maintenance of the $\mathrm{Po}_{\text {bic }}$ contents is possible, but also the elevation in the contents of this form of $\mathrm{P}$, as reported by Chen et al. (2002) and Helal and Sauerbeck (1984).

The contents of $\mathrm{Pi}_{\text {hid' }} \mathrm{Po}_{\text {hid' }}, \mathrm{P}_{\mathrm{HCl}}$ and $\mathrm{P}_{\text {residual }}$ were not influenced by cultivation of plants (Figure 3) because these forms of $\mathrm{P}$ are considered less labile, and the cultivation period was very short and the need for $\mathrm{P}$ by the crops was low. The smaller the quantity of inorganic $\mathrm{P}$
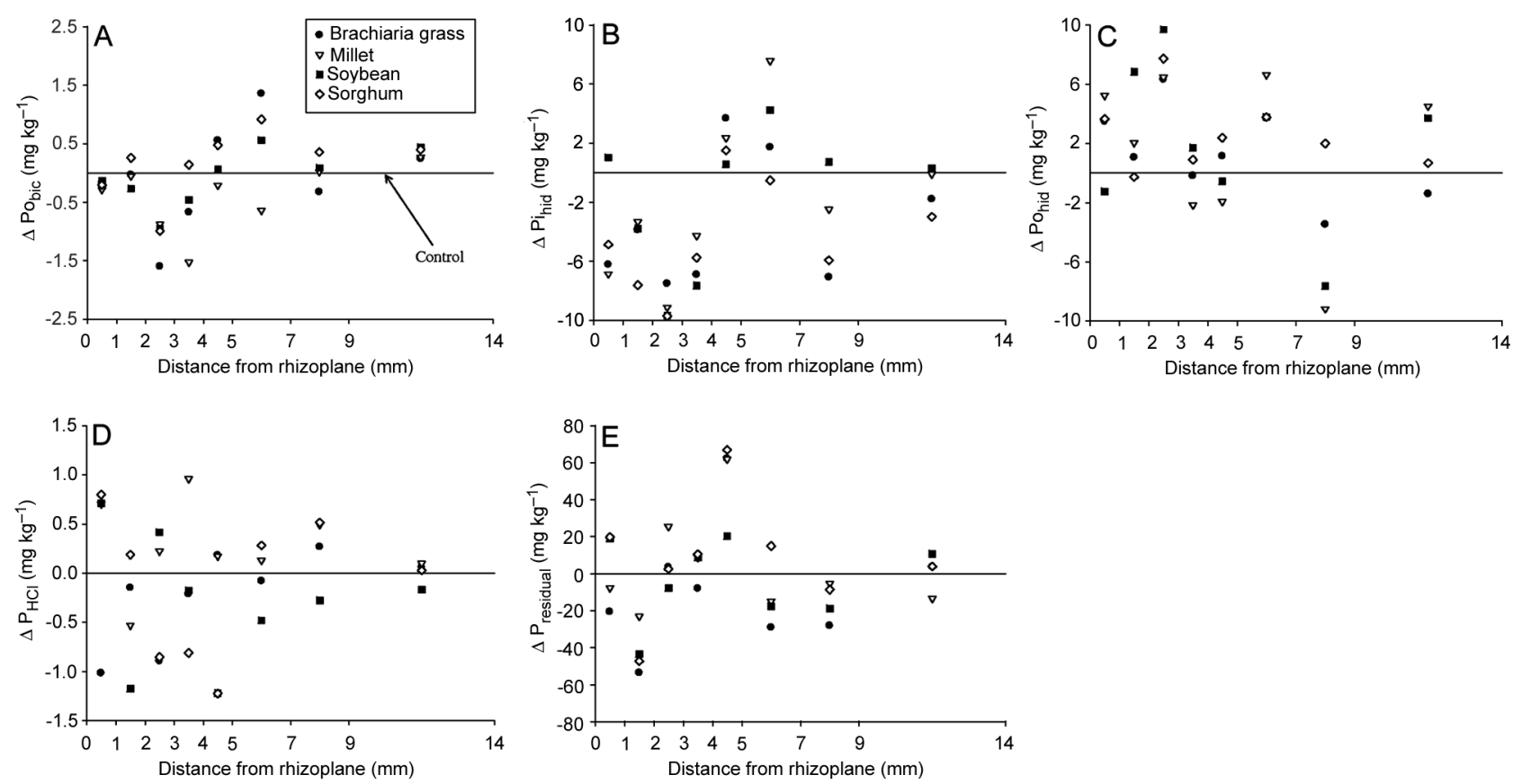

Figure $3-\mathrm{Po}_{\text {bic }}(A), \mathrm{Pi}_{\text {hid }}(B), \mathrm{Po}_{\text {hid }}(C), \mathrm{P}_{\text {HCI }}(D)$ and $\mathrm{P}_{\text {residual }}(E)$ differences between each treatment and control $(\Delta)$ in different layers of soil from the rhizoplane caused by the cultivation of different plants. In each layer, treatments did not differ from the control by the Dunnett test $(p \leq 0.05)$. 
available for plants, the greater the extrusion of phosphatases by plants with the objective of accessing organic forms of P (Hedley et al., 1983; Gatiboni et al., 2008). Therefore, the plants access the less available forms of $\mathrm{P}$ mainly when they need elevated quantities of $\mathrm{P}$ and there are low contents of the more labile forms of this nutrient (Gatiboni et al., 2007).

For the variables in which the effect of the cultivation of plants was observed, $\mathrm{P}_{\text {resin }}$ and $\mathrm{Pi}_{\text {bic }}$ alteration in their values were restricted to the layer nearest to the roots $(0-1 \mathrm{~mm})$, showing the spatial restriction of the alteration in the chemical attributes of the soil in terms of root development (Chen et al., 2002; Li et al., 2008; Zoysa et al., 1997) and indicating that the collection of a small layer of soil near the roots (up to $14 \mathrm{~mm}$ ) is sufficient for the evaluation of the $\mathrm{P}$ transformations in the rhizosphere. Nevertheless, the determination of the soil layer to be sampled in future studies should take into consideration diverse factors that interfere in the distance of root activity, such as evaluated attributes, soil buffer capacity, soil water content, nutrient uptake capacity by the plant and cultivation time.

There was variation in the $\mathrm{pH}$ values and in the contents of $\mathrm{P}$ forms with the increase of the distance from the rhizoplane in all treatments, including the control (data not shown). This fact is probably due to sedimentation of the finest soil and fertilizer particles which occurred at the time of filling of the PVC columns and, for that reason, there was no limitation in availability of $\mathrm{P}$ for the plants in the layers nearest the roots, bearing in mind the greater reactivity of finer particles. Therefore, in carrying out future experiments with the objective of studying soil layers at a millimetric scale, attention must be given to the reduction of particle sedimentation because this may generate uncontrolled variations among the experimental units and thus introducing experimental error. In this sense, filling the columns with moist soil may be a quickly and easily executed strategy to avoid the occurrence of sedimentation of particles of both soil and fertilizer.

The technique used for evaluation of the rhizosphere in this study is useful in evaluation of the occurrence of phenomena ( $\mathrm{P}$ uptake, for example). Nevertheless, the magnitude in which this phenomenon occurs is certainly different from that observed in normal crop conditions because the depth limitation of root growth due to the use of the $25 \mu \mathrm{m}$ mesh brings about significant concentration of roots in the region near the mesh, making the capacity for alterations in the soil attributes of the rhizosphere possible, as Zoysa et al. (1997) alert.

\section{Conclusions}

The $\mathrm{pH}$ of the rhizospheric soil was not affected by the cultivation of soybean, brachiaria grass, millet and sorghum. Sorghum led to depletion in the $\mathrm{P}_{\text {resin }}$ and $\mathrm{Pi}_{\text {bic }}$ contents, while brachiaria grass and millet led to depletion only in the $\mathrm{Pi}_{\text {bic }}$ contents. Alterations in the $\mathrm{P}_{\text {resin }}$ and
$\mathrm{Pi}_{\text {bic }}$ contents were restricted to the $0-1 \mathrm{~mm}$ soil layer from the rhizosphere.

\section{Acknowledgements}

The authors thank CAPES and CNPq for the scholarships.

\section{References}

Beck, M.A.; Sanches, P.A. 1994. Soil phosphorus fraction dynamics during 18 years of cultivation on a Typic Paleudult. Soil Science Society of America Journal 58: 1424-1431.

Bertrand, I.; Hinsinger, P.; Jaillard, B.; Arvieu, J.C. 1999. Dynamics of phosphorus in the rhizosphere of maize and rape grown on synthetic, phosphated calcite and goethite. Plant and Soil 211: 111-119.

Chen, C.R.; Condron, L.M.; Davis, M.R.; Sherlock, R.R. 2002. Phosphorus dynamics in the rhizosphere of perennial ryegrass (Lolium perenne L.) and radiate pine (Pinus radiate D. Don.). Soil Biology and Biochemistry 34: 487-499.

Ernani, P.R. 2008. Soil chemistry and nutrient availability. The author, Lages, SC, Brazil. (in Portuguese).

Gatiboni, L.C.; Kaminski, J.; Rheinheimer, D.S.; Brunetto, G. 2008. Soil microbial biomass phosphorus and activity of acid phosphatases during decline of soil available phosphorus. Pesquisa Agropecuária Brasileira 43: 1085-1091 (in Portuguese, with abstract in English).

Gatiboni, L.C.; Kaminski, J.; Rheinheimer, D.S.; Flores, J.P.C. 2007. Bioavailability of soil phosphorus forms in no-tillage system. Revista Brasileira de Ciência do Solo 31: 691-699 (in Portuguese, with abstract in English).

Grant, C.A.; Flaten, D.N.; Tomasiewicz, D.J.; Sheppard, S.C. 2001. The importance of phoshorus in the inicial development of plants. p. 1-5. In: Potafos. Agronomic Information. Potafos, Piracicaba, SP, Brazil (in Portuguese).

Guo, F.; Yost, R.S. 1998. Partitioning soil phosphorus into three discrete pools of differing availability. Soil Science 163: 822-833.

Hedley, M.J.; Nye, P.H.; White, R.E. 1983. Plant-induced changes in the rhizosphere of rape (Brassica napus Var. Emerald) seedlings. IV. The effect of rhizosphere phosphorus status on the $\mathrm{pH}$, phophatase activity and depletion of soil phosphorus fractions in the rhizosphere and on the cation-anion balance in the plants. New Phytologist 95: 69-82.

Hedley, M.J.; Stewart, J.W.B.; Ghauhan, B.S. 1982. Changes in inorganic soil phosphorus fractions induced by cultivation practices and laboratory incubations. Soil Science Society of America Journal 46: 970-976.

Helal, H.M.; Sauerbeck, D.R. 1984. Influence of plant roots on C and P metabolism in soil. Plant and Soil 76: 175-182.

Henriquez, C.; Killorn, R. 2005. Soil P forms and P uptake under intensive plant growth in the greenhouse. Agronomia Costarricense 29: 83-97.

Hinsinger, P.; Gilkes, R.J. 1995. Root-induced dissolution of phosphate rock in the rhizosphere of lupins grown in alkaline soil. Australian Journal of Soil Research 33: 477-489.

Hinsinger, P.; Gilkes, R.J. 1997. Dissolution of phosphate rock in the rhizosphere of five plant species grown in an acid, $\mathrm{P}$ fixing mineral substrate. Geoderma 75: 231-249. 
Hinsinger, P.; Gilkes, R.J. 1996. Mobilization of phosphate from phosphorus rock and alumina-sorbed phosphate by the roots of ryegrass and clover as related to rhizosphere $\mathrm{pH}$. European Journal of Soil Science 47: 533-544.

Kuchenbuch, R.; Jungk, A. 1982. A method for determining concentration profiles at the soil-root interface by thin slicing rhizospheric soil. Plant and Soil 68: 391-394.

Li, H.; Shen, J.; Zhang, F.; Clairotte, M.; Drevon, J.J.; Le Cadre, E.; Hinsiger, P. 2008. Dynamics of phosphorus fractions in the rhizosphere of common bean (Phaseolus vulgaris L.) and durum wheat (Triticum turgidum durum L.) grown in monocropping and intercropping systems. Plant and Soil 312: 139-150.

Martin, J.K. 1983. Biology of rhizosphere: soils; an Australian viewpoint. CSIRO/Academic Press, Melbourne, VIC, Australia.

Morel, C.; Hinsinger, P. 1999. Root-induced modifications of the exchange of phosphate ion between soil solution and soil solid phase. Plant and Soil 21: 103-110.

Murphy, J.; Riley, J.P. 1962. A modified single solution methods for the determination of phosphate in natural waters. Analytica Chimica Acta 27: 31-36.

Pearse, S.J.; Veneklaas, E.J.; Cawthray, G.; Bolland, M.D.A.; Lambers, H. 2007. Carboxylate composition of root exudates does not relate consistently to a crop species ability to use phosphorus from aluminium, iron or calcium phosphate sources. New Phytologist 173: 181-190.

Pearse, S.J.; Veneklaas, E.J.; Cawthray, G.; Bolland, M.D.A.; Lambers, H. 2006. Triticum aestivum shows a greater biomass response to a supply of aluminium phosphate than Lupinus albus despite releasing fewer carboxylates into the rhizosphere. New Phytologist 169: 515-524.

Perez, M.J.; Smyth, T.J.; Israel, D.W. 2007. Comparative effects of two forage species on rhizosphere acidification and solubilization of phosphate rocks of different reactivity. Journal of Plant Nutrition 30: 1421-1439.

Prochnow, L.I.; Alcarde, J.C.; Chien, S.H. 2004. Agronomic efficience of acidulated phosphate. p. 605-651. In: Yamada, T.; Abadalla, S.R.S., eds. Phosphorus in Brazilian agriculture. Potafos, Piracicaba, SP, Brazil (in Portuguese).

Ramirez, R.; Fernandez, S.M.; Lizaso, J.I. 2001. Changes of $\mathrm{pH}$ and available phosphorus and calcium in rhizosphere of aluminum-tolerant maize germplasm with phosphate rock. Communications in Soil Science and Plant Analysis 32: 15511565.

Robinson, J.S.; Syers, J.K. 1990. A critical evaluation of the factors influencing the dissolution of Gafsa phosphate rock. Journal of Soil Science 41: 597-605.

Ros, C.; Bell, R.W.; White, P.F. 1997. Effect of seed phosphorus and soil phosphorus applications on early growth of rice (Oryza sativa L.) cv. IR66. Soil Science and Plant Nutrition 43: 499509.

Sanyal, S.K.; Datta, S.K. 1991. Chemistry of phosphorus transformations in soil. Advanced Soil Science 16: 102-120.
Sharpley, A.N.; Smith, S.J. 1985. Fractionation of inorganic and organic phosphorus in virgin and cultivated soils. Soil Science Society of America Journal 49: 127-130.

Soil Survey Staff. 2010. Keys to soil taxonomy. 11ed. USDA-Natural Resources Conservation Service, Washington, D.C., USA.

Sousa, D.M.G.; Lobato, E. 2004. Lime and fertilizers for annual and perennial species. p. 283-316. In: Sousa, D.M.G.; Lobato, E., eds. Cerrado: soil liming and fertilization. 2ed. Embrapa Cerrados, Planaltina, GO, Brazil (in Portuguese).

Sousa, D.M.G.; Lobato, E.; Rein, T.A. 2004. Phosphorus fertilization. p. 147-168. In: Souza, D.M.G.; Lobato, E., eds. Cerrado: soil liming and fertilization. 2ed. Embrapa Cerrados, Planaltina, GO, Brazil (in Portuguese).

Stewart, J.W.B.; Tiessen, H. 1987. Dynamics of soil organic phosphorus. Biogeochemistry 4: 41-60.

Tedesco, M.J.; Gianello, C.; Bissani, C.A.; Bohnen, H.; Volkweiss, S.J. 1995. Analyis of soils, plants and other organic materials. UFRGS/FA/DS, Porto Alegre, RS, Brazil (in Portuguese).

Tiessen, H.; Stewart, J.W.B.; Cole, C.V. 1984. Pathways of phosphorus transformations in soils of differing pedogenesis. Soil Science Society of America Journal 48: 853-858.

Thomson, C.J.; Bolger, T.P. 1993. Effects of phosphorus concentration on the emergence and growth of subterranean clover (Trifolium subterraneum). Plant and Soil 155/156: 285288.

Toal, M.E.; Yeomans, C.; Killham, K.; Meharg, A.A. 2000. A review of rizhosphere carbon flow modeling. Plant and Soil 222: 263-281.

Trigo, L.F.N.; Peske, S.T.; Gastal, F.C.; Vahl, L.C.; Trigo, M.F.O. 1997. Effect of phosphorus concentration in the seed on the yield of soybean. Revista Brasileira de Sementes 19: 111-115 (in Portuguese, with abstract in English).

Zhang, M.; Nyborg, M.; McGill, W.B. 1990. Phosphorus concentration in barley (Hordeum vulgare L.) seed: influence on seedling growth and dry matter production. Plant and Soil 122: 79-83.

Zhu, Y.G.; Smith, S.E. 2001. Seed phosphorus (P) content affects growth, and $\mathrm{P}$ uptake of wheat plants and their association with arbuscular mycorrhizal (AM) fungi. Plant and Soil 231: 105-112.

Zoysa, A.K.N.; Loganathan, P.; Hedley, M.J. 1998. Effect of forms of nitrogen supply on mobilization of phosphorus from a phosphate rock and acidification in the rhizosphere of tea. Australian Journal of Soil Research 36: 373-387.

Zoysa, A.K.N.; Loganathan, P.; Hedley, M.J. 1997. A technique for studying rhizosphere processes in tree crops: soil phosphorus depletion around camellia (Camellia japonica L.) roots. Plant and Soil 190: 253-265. 